\title{
The Bible in the films of Pavel Lungin and Andrei Zvyagintsev
}

\author{
Marek Lis iDhtp://orcid.org/0000-0001-6387-2621 \\ Faculty of Theology \\ Opole University \\ marek.lis@uni.opole.pl
}

\begin{abstract}
In the Soviet Union, even after perestroika, explicitly biblical films have practically not been produced; nevertheless the Bible, despite acute censorship, has been present in a symbolic way in films directed by Andrei Tarkovsky and Larissa Shepitko. A certain revival of biblical themes is evident in recent works of Russian directors Pavel Lungin (Island, 2006; The Conductor, 2012), and Andrei Zvyagintsev (The Return, 2003; Leviathan, 2014). The paper analyzes the meaning of the Bible in these films: biblical texts are quoted in dialogues, and evoked in the titles and the protagonists' names; biblical motifs are present in images, in contemporary events, and in the narrative structures. The Bible is recognizable in the experiences of the protagonists (Christ figures), and it influences their lives, or is refused and denied. Lungin and Zvyagintsev show the importance of the Bible in challenging personal, social, religious and political contexts and situations.
\end{abstract}

Keywords: Russian film, Bible, cinema, Lungin, Zvyagintsev

Słowa kluczowe: film rosyjski, Biblia, kino, Łungin, Zwiagincew

The Bible, both the Old and New Testaments, and particularly the Gospels, is still inspiring film directors and attracting audiences. Produced recently in diverse countries and cultures, ${ }^{1}$ numerous biblical films, for the cinema and for television, portray historical figures (Judas, dir. Charles Robert Carner, 2002; The Passion of the

${ }^{1}$ A rich bibliography is available, e.g.: F.L. Bakker, The Challenge of the Silver Screen: An Analysis of the Cinematic Portraits of Jesus Rama, Buddha and Muhammad, Leiden-Boston 2009; Bible and Cinema: Fifty Key Films, A. Reinhartz (ed.), New York 2013; The Blackwell Companion to Jesus, D. Burkett (ed.), Hoboken 2011; Cinematic Transformations of the Gospel, M. Lis (ed.), Opole 2013; Jesus in Twentieth-Century Literature, Art, and Movies, Paul C. Burns (ed.), New York-London 2007; T. Langkau, Filmstar Jesus Christus. Die neuesten Jesus-Filme als Herausforderung für Theologie und 
Christ, dir. Mel Gibson, 2004; Maria di Nazaret [Mary of Nazareth], dir. Giacomo Campiotti, 2012; Paul, Apostle of Christ, dir. Andrew Hyatt, 2018); interpret protagonists of the Bible through a filter of racial issues (Jesus is black in Son of Man, dir. Mark Dornford-May, 2006, and Color of the Cross, dir. Jean-Claude LaMarre, 2006) and other religions (Iranian films on Jesus Al-Masih [The Messiah], dir. Nader Talabzadeh, 2007, and on Mary Maryam al-Muqaddasah [Saint Mary], dir. Shariar Bahrani, 2007); propose new apocrypha (Io sono con te [Let It Be], dir. Guido Chiesa, 2010; The Young Messiah, dir. Cyrus Nowrasteh, 2016); and deconstruct the narration of the Bible (The Da Vinci Code, dir. Ron Howard, 2006; Mary Magdalene, dir. Garth Davis, 2018). The imagination of directors has allowed Jesus, the central figure of the New Testament, to appear in modern Israel ( $7 \mathrm{~km}$ da Gerusalemme, dir. Claudio Malaponti, 2007), the USA (Encounter, dir. David A.R. White, 2010; The Shack, dir. Stuart Hazeldine, 2017), Germany (Jesus liebt mich [Jesus Loves Me], dir. Florian David Fitz, 2011), and in Belgium (Les premiers, les derniers [The First, the Last], dir. Bouli Lanners, 2016).

In the Soviet Union, and in other ex-communist countries, even after perestroika, explicitly biblical films practically have not been produced, and ideological censorship is not the only reason: "Initially, the cinematic depiction of Jesus was a complete taboo. The Orthodox Church responded almost immediately to one portrayal of Jesus with a letter issued by the office of the Holy Synod in 1898: On the inadmissibility of holy subjects being shown by means of the so-called 'Living photography'."' Rare cases are an animated version of the Gospel in the British-Russian The Miracle Maker (dir. Derek W. Hayes, Stanislav Sokolov, 2000), and Iuda (Judas, dir. Andrey Bogatyrev, 2013); nevertheless the Bible, despite acute censorship, has been present in films in symbolic ways. Examples are Polish films directed by Krzysztof Zanussi (Struktura krysztalu [The Structure of Crystal], 1969; Constans [The Constant Factor], 1980) and Krzysztof Kieślowski (Dekalog, 1988), and Soviet films by Andrei Tarkovsky (Andrei Rublov [Andrei Rublev], 1966; Stalker, 1979) and Larissa Shepitko (Voskhozhdenie [The Ascent], 1977).

Nowadays, “After seven decades of systematic 'atheization,' Russia is exactly one of the countries where Christian values in the media and public opinion make a problematic area," 3 but a certain revival of biblical themes is evident in recent cinematic works of the Russian directors Pavel Lungin (Ostrov [Island], 2006; Dirizhyor [The Conductor], 2012), and Andrei Zvyagintsev (Vozvrashchenie [The Return], 2003; Leviafan [Leviathan], 2014): it is interesting to analyze the meaning of biblical motifs in these films.

Religionspädagogik, Berlin 2007; P. Malone, Screen Jesus: Portrayals of Christ in television and film, Lanham-Toronto-Plymouth 2012; A. Reinhartz, Bible and Cinema: An Introduction, New York 2013.

2 J. Mitchell, Understanding Religion and Film in "Postsecular Russia", [in:] Religion in Contemporary European Cinema: The Postsecular Constellation, C. Bradatan, C. Ungureanu (eds.), New YorkLondon 2014, p. 195.

${ }^{3}$ V. Khroul, Christian Values in the Russian Media and Public Opinion: Why SIGNIS Spirit is so Needed, [in:] SIGNIS and Cinema: Looking for God behind the Screen, M. Lis (ed.), Bruxelles-Opole 2016, p. 37. 


\section{Pavel Lungin: The Bible in the Orthodox sphere}

There is no doubt that Pavel Lungin, born in 1949 in Moscow, explores religious themes from a perspective of the Russian Orthodoxy in his films. His Ostrov (Island, 2006), situated in a northern monastery, describes a spiritual change of an unusual monk who has the power to heal, exorcise demons and foretell the future. Tsar (2009) is a morality play about the conflict between Ivan the Terrible, who believes he is vested with a holy mission while the Apocalyptical Last Judgment is approaching, and Philip, the superior of a monastery on the Solovetsky Islands, who dares to oppose the mystical tyranny of the Tsar: "In Lungin's film, the tsar appears, on the one hand, as a God-fearing doubter and, on the other, as a paranoid ruler with diabolical characteristics who is obsessed with the apocalypse." " The main protagonist of Dirizhyor (The Conductor, 2012) takes his orchestra to Jerusalem to execute the oratorio Passion According to St. Matthew. These films are also influenced by biblical themes: sin, penance, and reconciliation in Island, the Apocalypse in Tsar, and the Christ's Passion in The Conductor.

The first figure in Island is a monk, rowing a boat, who upon reaching land prays alone repeating the biblical words of the Jesus Prayer: "Lord Jesus Christ, Son of God, have mercy on me, a sinner." Then an intertitle ("War, 1942") opens a short night sequence: a Soviet coal barge is stopped by Germans, who blackmail a young Russian soldier; to save his own life, he must kill his captain. Mines placed by the Germans explode, and the next morning monks find the soldier on the seashore.

In the eleventh minute of the film the second intertitle appears: "Monastery, 1976". Since 1942 the saved (and guilty) soldier has lived there as Father Anatoly (Petr Mamonov), solitary on the margins of the ordinary monastery life: he provides coal for the furnace, bringing it from the shipwreck. ${ }^{5}$ Anatoly "is within the monastery but not integrated in its order, within the world but estranged from it; as such, he is the man of God in whom grace manifests itself freely and visibly," ${ }^{\prime 6}$ but he is famous outside: people come to the island to talk to him, to search for solutions to their problems, believing he is a miracle maker, a starets. Indeed, he is able to foretell the future, and he heals a boy, but his life is a constant penance. Words from the Bible penetrate the film, in the recitation of the Jesus Prayer, or of the Psalm: "Have mercy on me, O God, according to your unfailing love; according to your great compassion blot out my transgressions... Cleanse me with hyssop, and I will be clean; wash me, and I will be whiter than snow... and renew a steadfast spirit within me... Do not cast me from your presence or take your Holy Spirit from me." (Ps 51,3-13) ${ }^{7}$

${ }^{4}$ E. Binder, Rethinking History: Heroes, Saints, and Martyrs in Contemporary Russian Cinema, [in:] Iconic Turns: Nation and Religion in Eastern European Cinema since 1989, L. Berezhnaya, C. Schmitt (eds.), Leiden-Boston 2013, p. 152.

${ }^{5}$ Final credits inform that the film was shot in one of the Solovetsky Monasteries of Kem, on the shores of the White Sea.

${ }^{6}$ A. Birzache, "Casting Fire Onto the Earth": The Holy Fool in Russian Cinema, [in:] Religion in Contemporary European Cinema: The Postsecular Constellation, C. Bradatan, C. Ungureanu (eds.), New York-London 2014, p. 32.

7 NIV Holy Bible, Grand Rapids MI 2001, p. 314. 
Father Job (a biblical name) is the antagonist of Anatoly: he denounces Anatoly to the superior of the community, saying that Anatoly does not wash his hands and face, comes late to the church, and meets ordinary people and drinks tea with them. These complaints remind us of the accusations against Jesus and his disciples: "Then some Pharisees and teachers of the law came to Jesus from Jerusalem and asked: Why do your disciples break the tradition of the elders? They don't wash their hands before they eat!" (Mt 15,1-2), and "When the teachers of the law who were Pharisees saw him eating with the 'sinners' and tax collectors, they asked his disciples: Why does he eat with tax collectors and 'sinners'? On hearing this, Jesus said to them, 'It is not the healthy who need a doctor, but the sick. I have not come to call the righteous, but sinners." (Mk 2,16-17)

The structure of the film is characteristic: sequences of Anatoly's meetings with people who need his help are interwoven with biblical words, repeated by the monk. After the healing of the boy Vanya (and before the night scene with Filaret) Anatoly recites another Psalm: "Blessed is the man who does not walk in the counsel of the wicked or stand in the way of sinners or sit in the seat of mockers. But his delight is in the law of the LORD, and on his law he meditates day and night." (Ps 1) "He [Anatoly] is often shown next to the furnace or carrying coal for its maintenance - his deliberate association with fire evoking a wide range of symbolic meanings from the Holy Spirit to the fires of the Last Judgment, forces both creative and destructive. Indeed, endowed with divine awareness and discernment of spirits, he keeps alight the spiritual fire for the whole monastery, and his mysterious acts provoke others into a state of self-reflection."

The film can be interpreted in several ways: H.-J. Schlegel observes that Lungin in Island "transfers religious questions from Dostoyevsky's novel Crime and Punishment into a popular cinematic story, which makes it seem even more impressive," but the biblical inspiration of the film is evident. Citation of the biblical Psalms may suggest references to King David, a man chosen by God and a repentant sinner. Mariola Marczak sees in the film "a meditation on the Pauline vision of wicked nature, though with traces of God's image." 10 For Andrzej Szpulak, Anatoly bears traits of two types of Russian "men of God": yurodivy, the Holy Fool, and starets, the venerated spiritual adviser. People go to the monastery convinced that Anatoly is a starets: he is able to predict future events, he fights against his own demons and weaknesses, and to express his thoughts he quotes from the Bible, like starets do. ${ }^{11}$ Without any doubt, such an intensive presence of biblical texts, especially fragments of the Gospel and Psalms, in Island is not question of a mere ornamentation well-adapted to a story

\footnotetext{
${ }^{8}$ A. Birzache, op. cit., p. 31.

${ }_{9}$ H.-J. Schlegel, Religion and Politics in Soviet and Eastern Cinema, [in:] Iconic Turns..., op. cit., p. 55.

${ }^{10}$ M. Marczak, Teologia grzechu i świętości w ,Wyspie” Pawła Łungina, [in:] Kultura wizualna teologia wizualna, W. Kawecki, J.S. Wojciechowski, D. Żukowska-Gardzińska (eds.), Warszawa 2011, p. 199.

${ }^{11}$ A. Szpulak, Filmy Pawla Eungina ,Car” $i$,Wyspa” wobec duchowej tradycji rosyjskiego prawostawia, [in:] Sacrum w kinie dekadę później. Szkice, eseje, rozprawy, S.J. Konefał, M. Zelent, K. Kornacki (eds.), Gdańsk 2013, pp. 150-153.
} 
about monks: Father Anatoly bears resemblance to David (penance), St. Paul (as Christ's converted disciple aware of his weakness), and is even seen as a Christ figure (as thaumaturge and teacher).

The Bible is essential to understanding Lungin's The Conductor (2012). Its story seems uncomplicated: Moscow musicians are rehearsing for a premiere of St. Matthew Passion, as the oratorio will be performed in Jerusalem. The Passion in the film is a real musical work for orchestra and voices, composed by orthodox Russian Metropolitan Hilarion Alfeyev in 2006. ${ }^{12}$ Extradiegetic music from the Passion plays an important role from the first sequences of the film, from the austere landscapes of the Judean Desert and the Dead Sea, to the streets of Jerusalem, to the comfortable interiors of the Moscow apartment of Slava (Vladas Bagdonas), the titular character. Slava, awoken by an incoming fax, seems disturbed. Later, during the rehearsal, he informs the musicians that their journey to Jerusalem will be sooner than anticipated. After arriving in Jerusalem, Slava he takes a taxi and goes to a house, where a commune of young people lives. There his son Sasha has committed suicide: Slava buys a picture, painted by Sasha. It i's a portrait of the dead Christ, with the face of Slava. A parallel montage introduces several themes of the film: the last rehearsals for preparations of the Passion and its premiere, the personal drama of Slava and funeral of his son, and preparation of an Islamic terrorist preparing to a suicide bomb attack. In the concert hall, Exactly in at the moment when in the concert hall the evangelist sings about the death of Jesus, a bomb hidden under the clothes of the terrorist, disguised as an orthodox Jew, explodes. The next day, Slava walks to the tomb of his son and leaves there a letter, cries, and enters the Church of the Resurrection. The music in the final sequence - always the same Russian Passion - is a chorale "You rose from the dead, Halleluiah, glory to You."

In The Conductor Pavel Lungin creates a multidimensional Passion play, resembling Jésus de Montréal (Jesus of Montreal, dir. Denys Arcand, 1989): in the Canadian film the Passion is announced in the music (Pergolesi's Stabat Mater), refreshed for the public in the mystery play performed by Daniel Coulombe, and finally experienced tragically by himself and his actors. In Lungin's film, the central event is the Jerusalem premiere of the St. Matthew Passion, prepared by Slava: the music of the Passion, both the diegetic (during rehearsal and performance of the oratorio) and extradiegetic (as commentary to what happens), creates the film's narrative. Its protagonists are the real participants in this Passion: first the director, whose face Sasha painted as the face of the Christ. Does Slava throw away the picture to categorically sever relations with his late son, or to avoid mention of the death he fears, or to eliminate suffering from his own life? Yet, there is a change in Slava's attitude: after he visits his son's grave, and the Church of the Resurrection. Is there an allusion to the Gospel, where after the drama of the cross comes the hope of the Resurrection? Slava evokes perhaps the Apostle Peter, who - terrified by the perspective of death - first denies Jesus, then cries (Mt 26,69-75), and after the Resurrection affirms his love (Jn 21,15-17)? Thus, Sasha could be interpreted as a Christ figure. A passion figure

${ }^{12}$ This eclectic Passion premiered on $27^{\text {th }}$ March 2007 in Moscow, A. Vorozhko, Muzyka zwrócona ku Bogu, "Elpis" 2012, no. 25-26, p. 431. 
is Olga, the Russian pilgrim killed in the bomb explosion at the moment when - in the musical Passion - Jesus dies. The terrorist can be seen as a diabolical, inverted Passion figure: while the death of Jesus brings hope (unlike Bach, Alfeyev ends his Passion with the Resurrection), the act of suicide brings about the death of innocents. Disguised as a Jew, the Palestinian terrorist is a Judas figure as liar. Alfeyev included in his Passion a musical motif composed by Zbigniew Preisner ${ }^{13}$ for the Dekalog, 6 (dir. Krzysztof Kieślowski, 1988), where Tomek is a Christ figure. ${ }^{14}$ In Lungin's film, this motif accompanies the death of Jesus on the cross.

\section{Andrei Zvyagintsev: the Bible in deserted areas}

Born in 1964 in Novosibirsk, "Andrey Zvyagintsev undoubtedly belongs to the group of "faith-fueled film makers." "15 Indeed, his films explore issues of spirituality and actualize the message of the Bible (The Return, 2003), but they also express the director's criticism of the role of the Orthodox Church in Russia (in Leviathan, 2014, and Loveless, 2017).

His feature film debut, Vozvrashchenie (The Return, 2003), winner of numerous film festivals (five awards in Venice), and of the European Film Award in 2003, tells the story of a mysterious return home of a man (Konstantin Lavronenko), after being absent for twelve years. The man, unknown to his teenage sons, takes them on a holiday to a remote lake in the north of Russia, where a tragedy happens and the father dies.

From the beginning, the story is marked by biblical allusions: its structure is organized around the seven days of the week, starting on Sunday. Intertextual references evoke biblical themes: when the boys see their father for the first time they do not remember him (they know his photo kept in their Bible), he is photographed sleeping in a position that recalls Andrea Mantegna's painting Cristo morto (or Lamento sul Cristo morto, The Lamentation over the Dead Christ), reproduced by Pier Paolo Pasolini in Mamma Roma (1962), and by Krzysztof Kieślowski in Dekalog, 2 (1988). ${ }^{16}$ As H.-J. Schlegel observes, "Zvyagintsev ties the biblical story of Abraham's sacrifice of his son Isaac (which had already inspired Eisenstein's movie Bezhin lug) to a contemporary conflict between a father and his two sons. Ivan and Andrei discover a photograph of their long-absent father in a book with exactly this biblical scene." ${ }^{\prime 17}$ Yet, the German film historian and film critic does not note that this book, conserving the record of the father, is actually the Bible.

Their first meeting, at lunch, recalls the Last Supper of Jesus and his disciples: in a symbolic gesture, the father shares with his wife and sons meat instead of bread.

${ }_{13}$ M. Lis, Figury Chrystusa w „Dekalogu” Krzysztofa Kieślowskiego, Opole 2013, p. 127.

${ }^{14}$ L. Baugh, Imaging the Divine: Jesus and Christ-Figures in Film, Kansas City 1997, pp. 172-184.

${ }^{15}$ L. Berezhnaya, Longing for the Empire: State and Orthodox Church in Russian Religious Films, [in:] Iconic Turns..., op. cit., p. 104.

${ }^{16}$ M. Lis, op. cit., p. 89.

${ }^{17}$ H.-J. Schlegel, op. cit., p. 55. 
Marek Kotyński indicates biblical allusions in The Return: the father is compared to the Dead Christ; his photograph is found on an illustration of the story of Abraham, ready to sacrifice his son on Mount Moriah (Gen. 22,1-19); the scene of their first meal alludes to the Last Supper, prefiguration of His Passion (Mt 26,26-28), and also refers to the 'Supper in Emmaus' (Lk 24,13-33), "when the sacrificial gesture of 'breaking bread' allows two disciples to recognize the Risen Lord." These biblical references open ways for interpretation, and "inspire to discover associations and religious symbols in subsequent incidents, gestures and elements of the film action." 18

Andrei Zvyagintsev himself stressed that biblical "associations like these were very much intentional; and that religious questions, questions about the meaning of life, were important for him." ${ }^{\prime 19}$ In the cited article Kotyński thoroughly analyzes biblical elements in the film: the relationship with the father (or - in the biblical sense - Father), the discipleship of the two sons (father as a possible Christ figure), the struggle with the father (or - symbolically - with God), and the tragic death and burial of the father: "The long, final sequence with the sons who are staring at the dead body of their father on a boat, bears hallmarks of dramatic and yet pious adoration for Christ's sacrifice of love and the worshipped Body of Christ." ${ }^{20}$ The critics, however, do not analyse the structure of the film: the narrative starts on Sunday, with an unclear underwater image of a sunken boat; intertitles indicate the following days of the week, until Saturday, when the father (who dies on a Friday, like Jesus), is "buried" in the sinking boat. Is it the same sunken boat we see empty in the overture, before it all happens? Is the order of symbolical, biblical events in the film inverted (boat/empty grave - sleeping father/Dead Christ - Resurrection - meal with family/ Last Supper or Emmaus - discipleship - death of father) in order to stress the return of the father/Christ figure? Perhaps Andrey Zviagintsev organized the narration in the endless structure of the Möbius strip to recall the eternal return of Christ, a fascination of the Orthodox writers Fyodor Dostoyevsky and Nikos Kazantzakis.

For numerous viewers the first contact with a film is its poster. The poster of Leviafan (Leviathan, 2014) is a photograph of a seashore with a huge white skeleton of a whale, and a boy sitting nearby on a rock: this image could suggest presence of a sea monster in the film, but the protagonist, Kolya (Aleksey Serebryakov) is forced to defend his family against the corrupt mayor of a small coastal town in the Barents Sea after the local corrupted tribunal decides that Kolya's house would be demolished. Kolya calls a friend, lawyer, to help, but the local establishment wins the struggle. A church is built on the site of Kolya's house.

The title of Leviathan evokes an enigmatic sea monster, identified in different books of the Bible with the whale and the crocodile (Job 3,8, Job 41, Ps 74,14, Ps 104,26), or with the Devil, God's enemy ("Leviathan the gliding serpent," Isa 27,1).

In the Book of Job it is God Himself who talks to Job:

${ }^{18}$ M. Kotyński, Wrestling with God: The Paschal Path of Christ's Disciple in The Return by Andrei Zvyagintsev, [in:] Cinematic Transformations..., op. cit., pp. 137-139.

${ }^{19}$ H.-J. Schlegel, op. cit., p. 55.

${ }^{20}$ M. Kotyński, op. cit., p. 147. 
"Can you pull in the leviathan with a fishhook or tie down his tongue with a rope? Can you put a cord through his nose or pierce his jaw with a hook? Will he keep begging you for mercy? Will he speak to you with gentle words? Will he make an agreement with you for you to take him as your slave for life? Can you make a pet of him like a bird or put him on a leash for your girls? Will traders barter for him? Will they divide him up among the merchants? Can you fill his hide with harpoons or his head with fishing spears? If you lay a hand on him, you will remember the struggle and never do it again! Any hope of subduing him is false; the mere sight of him is overpowering." (Job 41,1-9) $)^{21}$

At least two biblical figures are evoked in Leviathan: the first is St. John the Baptist, whose icon can be shortly seen within the walls of a ruined church, where Kolya's son meets with friends in the evening, around a fire. John, the prophet from the banks of the Jordan, preached against the king Herod Antipas, who ordered his beheading (Mt 14,1-12). The head of St. John the Baptist symbolizes in the film the tragic fate of innocent honest people who oppose the power: Kolya "looks longingly to the dark heavens beyond the church's dilapidated ceiling, yet finds no answers. Teetering on the brink of oblivion, his eyes land on a decaying fresco of the beheading of John the Baptist, a stark reminder that even God's most faithful servants are vulnerable to the destructive whims of the world's rulers." 22

The other biblical figure is Job, an innocent broken by suffering and by the loss of family and home. The mythical leviathan in the film is not a sea monster but the cruel invincible mayor, and the establishment of the town. This "leviathan" defeats Kolya's lawyer, provokes the death of Lilya, and finally "swallows" their house: in its place a church will be built. A Russian critic noted: "While analyses on the film focused most immediately on its realistic portrayal of Russia's traditional ills: political and bureaucratic corruption, alcoholism, and depression, a broader critique engaged with its philosophical, religious and literary allusions, which added weight and complexity to the film's treatment of thematic issues." ${ }^{23}$ Kolya, aware of the dangers of his situation, asks, "Why, Lord?" and Father Vasiliy, a simple priest not involved with the local rulers, tries to answer. "Comparing Kolya to Job, who was likewise 'preoccupied with the meaning of life' as he underwent unbelievable hardship, Father Vasiliy points out that the latter was blessed only after he had 'resigned himself to his fate.' Although it is a well-intended lesson, Father Vasiliy unwittingly encourages Kolya's acquiescence not to the mysteries of God, but to the injustices piled upon him by, in large part, the priest's own church. Whatever small comfort it may offer its adherents, Zvyagintsev portrays the Russian Orthodox Church as an essentially unspiritual extension of a governing system maintained through deception, intimidation, and control.".24

${ }^{21}$ NIV Holy Bible, op. cit., p. 297.

22 D.J. Bekkering, Leviathan, "Journal of Religion \& Film" 2015, vol. 19, is. 1, art. 45.

23 J. Vasilieva, The Excesses of Power: Leviathan (Andrey Zvyagintsev, 2014), http://sensesofcinema.com/2017/soviet-cinema/2014-leviathan-andrey-zvyagintsev/ [access: 14.09.2018].

${ }^{24}$ D.J. Bekkering, op. cit. 
Although the Russian directors did not turn out a biblical costume film, a biopic in the Hollywood style, the Bible is present in their films as an object, a book to read (The Return), as words pronounced by protagonists of the films (Island), or evoked in the titles and the protagonists' names (Leviathan, Job), in images, in contemporary events or in narrative structure (The Conductor), interpreted in symbolic or figurative ways. Thus the Bible is not just a book, a specimen of ancient literature, but is still living in the experience of the people (Kolya as Job), influencing their lives (Anatoly), or - on the contrary - the Bible is refused and denied (the Orthodox hierarch in Leviathan). Both Lungin and Zvyagintsev, as numerous directors have before them, ${ }^{25}$ reread the Bible, revive its archetypes (penance, suffering of the innocent, sacrifice), and show its critical significance and importance in challenging precise personal, social, religious or political contexts and situations. Such an actualization of the Bible is far deeper than overtly biblical films like The Bible series (dir. Crispin Reece, Tony Mitchell, Christopher Spencer, 2013), but only if the viewers are able to recognize the spiritual and literary sources as interpreted by the films' directors.

\section{References}

Bakker F.L., The Challenge of the Silver Screen: An Analysis of the Cinematic Portraits of Jesus Rama, Buddha and Muhammad, Leiden-Boston 2009.

Baugh L., Imaging the Divine: Jesus and Christ-Figures in Film, Kansas City 1997.

Bekkering D.J., Leviathan, "Journal of Religion \& Film” 2015, vol. 19.

Berezhnaya L., Longing for the Empire: State and Orthodox Church in Russian Religious Films, [in:] Iconic Turns: Nation and Religion in Eastern European Cinema since 1989, L. Berezhnaya, C. Schmitt (eds.), Leiden-Boston 2013, pp. 99-120.

Bible and Cinema: Fifty Key Films, A. Reinhartz (ed.), New York 2013.

Binder E., Rethinking History: Heroes, Saints, and Martyrs in Contemporary Russian Cinema, [in:] Iconic Turns: Nation and Religion in Eastern European Cinema since 1989, L. Berezhnaya, C. Schmitt (eds.), Leiden-Boston 2013.

Birzache A., "Casting Fire Onto the Earth": The Holy Fool in Russian Cinema, [in:] Religion in Contemporary European Cinema. The Postsecular Constellation, C. Bradatan, C. Ungureanu (eds), New York-London 2014, pp. 27-43.

The Blackwell Companion to Jesus, D. Burkett (ed.), Hoboken 2011.

Cinematic Transformations of the Gospel, M. Lis (ed.), Opole 2013.

Jesus in Twentieth-Century Literature, Art, and Movies, Paul C. Burns (ed.), New York-London 2007.

Khroul V., Christian Values in the Russian Media and Public Opinion: Why SIGNIS Spirit is so Needed, [in:] SIGNIS and Cinema: Looking for God behind the Screen, M. Lis (ed.), Brussels-Opole 2016, pp. 37-50.

${ }^{25}$ E.g. Constans (The Constant Factor), dir. Krzysztof Zanussi, 1980; Babettes gaestebud (Babette's Feast), dir. Gabriel Axel, 1987; Dekalog, dir. Krzysztof Kieślowski, 1988; Jésus de Montréal (Jesus of Montreal), dir. Denys Arcand, 1989; The Matrix, dir L. and A. Wachowski, 1999; Chronicles of Narnia, dir. Andrew Adamson, 2005. 
Kotyński M., Wrestling with God: The Paschal Path of Christ's Disciple in The Return by Andrei Zvyagintsev, [in:] Cinematic Transformations of the Gospel, M. Lis (ed.), Opole 2013, pp. 137-148.

Langkau T., Filmstar Jesus Christus. Die neuesten Jesus-Filme als Herausforderung für Theologie und Religionspädagogik, Berlin 2007.

Lis M., Figury Chrystusa w „Dekalogu” Krzysztofa Kieślowskiego, Opole 2013.

Malone P., Screen Jesus: Portrayals of Christ in Television and Film, Lanham-Toronto-Plymouth 2012.

Marczak M., Teologia grzechu i świętości w ,Wyspie” Pawła Eungina, [in:] Kultura wizualna - teologia wizualna, W. Kawecki, J.S. Wojciechowski, D. Żukowska-Gardzińska (eds.), Warszawa 2011, pp. 197-206.

Mitchell J., Understanding Religion and Film in "Postsecular Russia", [in:] Religion in Contemporary European Cinema: The Postsecular Constellation, C. Bradatan, C. Ungureanu (eds.), New York-London 2014, pp. 186-198.

NIV Holy Bible, Grand Rapids MI 2001.

Reinhartz A., Bible and Cinema: An Introduction, New York 2013.

Schlegel H.-J., Religion and Politics in Soviet and Eastern Cinema, [in:] Iconic Turns: Nation and Religion in Eastern European Cinema since 1989, L. Berezhnaya, C. Schmitt (eds.), LeidenBoston 2013, pp. 33-61.

Szpulak A., Filmy Pawła Eungina ,Car" $i$,Wyspa” wobec duchowej tradycji rosyjskiego prawosławia, [in:] Sacrum w kinie dekade później. Szkice, eseje, rozprawy, S.J. Konefał, M. Zelent, K. Kornacki (eds.), Gdańsk 2013, pp. 147-156.

Vasilieva J., The Excesses of Power: Leviathan (Andrey Zvyagintsev, 2014), http://sensesofcinema. com/2017/soviet-cinema/2014-leviathan-andrey-zvyagintsev/ [access: 14.09.2018].

Vorozhko A., Muzyka zwrócona ku Bogu, "Elpis” 2012, no. 25-26, pp. 413-437. 